\title{
Modeling, testing, and parametric analysis of a parabolic solar cooking system with heat storage for indoor cooking
}

\author{
Ndiaga Mbodji and Ali Hajji
}

\begin{abstract}
Background: In an ever-changing world where needs increase daily due to economic growth and demographic progression, where prices are unstable, where reserves are running out, where climate change is topical, the energy issues are increasingly marked by the question of sustainability. In many developing countries, wood and subsidized butane are the main sources of energy used for cooking in households. The use of solar energy in domestic cooking becomes unavoidable. Several models of solar cookers have been proposed, but most of them dealt with box and oven types of solar cookers without storage.

Methods: This paper presents a dynamic thermodynamic model of a parabolic solar cooking system (PSCS) with heat storage, along with a comparison of the model solution with experimental measurements. The model uses various thermal resistances to take into account heat transfer between the different parts of the system.

Results: The first experimental setup consists of a parabolic concentrator (0.80-m diameter and 0.08-m depth) and a 1.57-I cylindrical receiver. The second experimental setup is composed of a parabolic concentrator (1.40-m diameter and 0.16-m depth), the same receiver, and a 6.64-I heat storage. Tests were carried out in Rabat, Morocco, between April 24 and July 10, 2014, and between May 15 and June 18,2015. Synthetic oil is used as a transfer fluid and a sensible heat storage.

Conclusions: Comparison between predicted and measured temperatures shows a good agreement with a relative error of $\pm 4.4 \%$. The effects of important system design and operating parameters were also analyzed. The results show that a $50 \mathrm{~W} \mathrm{~m}^{-2}$ increase of the daily maximum solar radiation increases the storage temperature by $4{ }^{\circ} \mathrm{C}$ and a $5 \%$ increase of the receiver reflectance or absorptance improves the maximum storage temperature by 3.6 and 3 . $9{ }^{\circ} \mathrm{C}$, respectively. Optimizing the aspect ratio of the receiver to 2 gives a maximum storage temperature of $85^{\circ} \mathrm{C}$. Increasing the thermal fluid mass flow rate from 0 to $18 \mathrm{~kg} \mathrm{~h}^{-1}$, or the receiver thermal insulation from 0.01 to 0 . $08 \mathrm{~m}$, increases the maximum storage temperature by 65 and $17^{\circ} \mathrm{C}$, respectively.
\end{abstract}

Keywords: Modeling, Parabolic solar cooking system, Heat storage, Parametric analysis

\section{Background}

With increasing population, economic growth, and environmental concerns, the use of solar energy in domestic cooking is becoming a good alternative for sustainable development which will greatly decrease mortality, deforestation, and soil erosion. The World Health Organization (WHO) reports that each year, 1.6 million people die from respiratory diseases caused by indoor air pollution due to

\footnotetext{
* Correspondence: m.ndiaga@yahoo.fr

Process Engineering and Environment Research Unit, Institut Agronomique et Vétérinaire Hassan II, BP 6202-Rabat-Instituts, 10101 Rabat, Morocco
}

solid fuel use for cooking [1]. A domestic solar cooker saves 100 trees in 15 years of life, prevents annually the release of 1.5 ton of $\mathrm{CO}_{2}$, increases the household purchasing power (by reducing the budget allocated to cooking), and gives more time to women and children who spend $15 \mathrm{~h}$ per week to the chore of wood [1].

While most solar cookers in use today do not have heat storage, this feature will alleviate the mismatch between solar heat energy supply and energy demand for cooking. Heat storage is important for indoor solar cooking requirements and will ensure continuity of service, reduce 
the use of conventional energy, and give a reasonable cooking time compared with conventional cooking [2].

Modeling solar concentrating systems including parabolic solar cooking systems (PSCS) is a key tool in order to increase their effectiveness and optimize their operating conditions. Several models of solar cookers have been proposed in the last years, but most of them dealt with box and oven types of solar cookers. Very little modeling work considered detailed dynamic temperature distribution and heat transfer in PSCS with storage. Existing models of parabolic solar systems-other than cooking applications-emphasize optimization of power production and not maximizing fluid temperature. In cooking systems, the fluid temperature determines not only the types of food that can be cooked but also the cooking time.

There is therefore a need to develop a detailed dynamic model of PSCS with heat storage, which will determine the temperature variations in all system components. The present work is focused on developing such a model and on its experimental validation. The "Brief literature review" section presents a brief literature review on the topic of modeling PSCS. The objective is to compare the different modeling approaches, the numerical solutions, the formulas used to assess heat losses, and their validation methods. The "System description and heat transfer processes" section describes the experimental system components and the heat transfer processes involved in its operation. Particular attention was given to the receiver, the key element which absorbs incoming solar radiation, converts it to heat, and transmits it to the heat transfer fluid. The "Governing equations and numerical solution" section gives the governing equations derived from heat balance relationships and heat transfer coefficient formulas and describes their numerical solution. The "Convergence and validation of the numerical solution" section presents the model validation by comparison with other known models and with the experimental results obtained from prototype testing. Finally, the "Parametric analysis" section gives the results of a parametric analysis on the effect of most relevant design elements and operating conditions.

\section{Brief literature review}

Solar cooking can be classified into four categories depending on the required temperature range: cooking ( 85 to $\left.90{ }^{\circ} \mathrm{C}\right)$, boiling $\left(100\right.$ to $\left.130{ }^{\circ} \mathrm{C}\right)$, frying $\left(200\right.$ to $\left.250{ }^{\circ} \mathrm{C}\right)$, and grilling (over $300{ }^{\circ} \mathrm{C}$ ) [3]. However, the most frequent classification on solar cooking systems distinguishes between direct and indirect systems [3]. In direct cookers, the solar heat is transferred directly from the reflective surface to the food container (casserole, pot, dish, etc.) whereas in indirect cookers, the pot is physically separate from the collector and a heat-transferring medium is required to convey the heat to the cooking pot. Both types can integrate or not a heat storage system whose size depends on the desired autonomy. Modern technologies often include internal large-scale kitchens for collective applications using fluid transfer with or without heat storage depending on the desired autonomy [3].

Most modeling of solar parabolic systems is concerned with Stirling engine applications, and only few studies have dealt with modeling such systems used in solar cooking. Mawire et al. [4] introduced the energy balance equations to model a solar energy capture (SEC) system and a thermal energy storage (TES) system for an indirect parabolic solar cooker. An oil-pebble bed is used as the TES material. A Simulink block was used to solve the equations and to perform energy and exergy analyses. The results indicate a greater degree of thermal stratification and energy stored when using constanttemperature charging than when using constant-flowrate charging. There are greater initial energy and exergy rates for the constant-flowrate method when the solar radiation is low. Energy efficiencies using both methods are comparable whilst the constant-temperature method results in greater exergy efficiency at higher levels of solar radiation. The same authors [5] used the system to carry out discharging simulations for the thermal energy storage system (TES). It was observed from the results that the TES system at a constant flow rate allows for a higher rate of heat utilization. However, this is not beneficial to the cooking process since the maximum cooking temperature is not maintained for the duration of the discharging period. On the other hand, the controlled load power discharging method (variable flow rate) has a slower initial rate of heat utilization but the maximum cooking temperature is maintained during the whole discharging process, and this is desirable for the cooking process. Prasanna [2] modeled and designed a hybrid solar cooking system consisting of a parabolic collector, a thermal storage tank, and a heat exchanger. The energy source is a combination of solar energy and liquefied petroleum gas (LPG). A bond graph modeling approach was used to build a dynamic model. He found an optimal flow rate allowed a $6 \%$ increase in system efficiency as compared to the thermosyphon flow rate. He also found that when the pipe diameter is decreased, the efficiency curve moves up. Mussard [6] developed a lowcost small-scale parabolic trough coupled with a thermal storage unit for higher temperature cooking. The system is built with a self-circulation loop and uses thermal oil. The thermal behavior of the system was simulated using the finite-volume method. He compared different sensible and latent heat storage materials and concluded on the relevance of latent heat-based systems. He also showed that a glass cover with an air gap around the absorber would not improve the efficiency at low temperatures, but when reaching high temperatures (around 

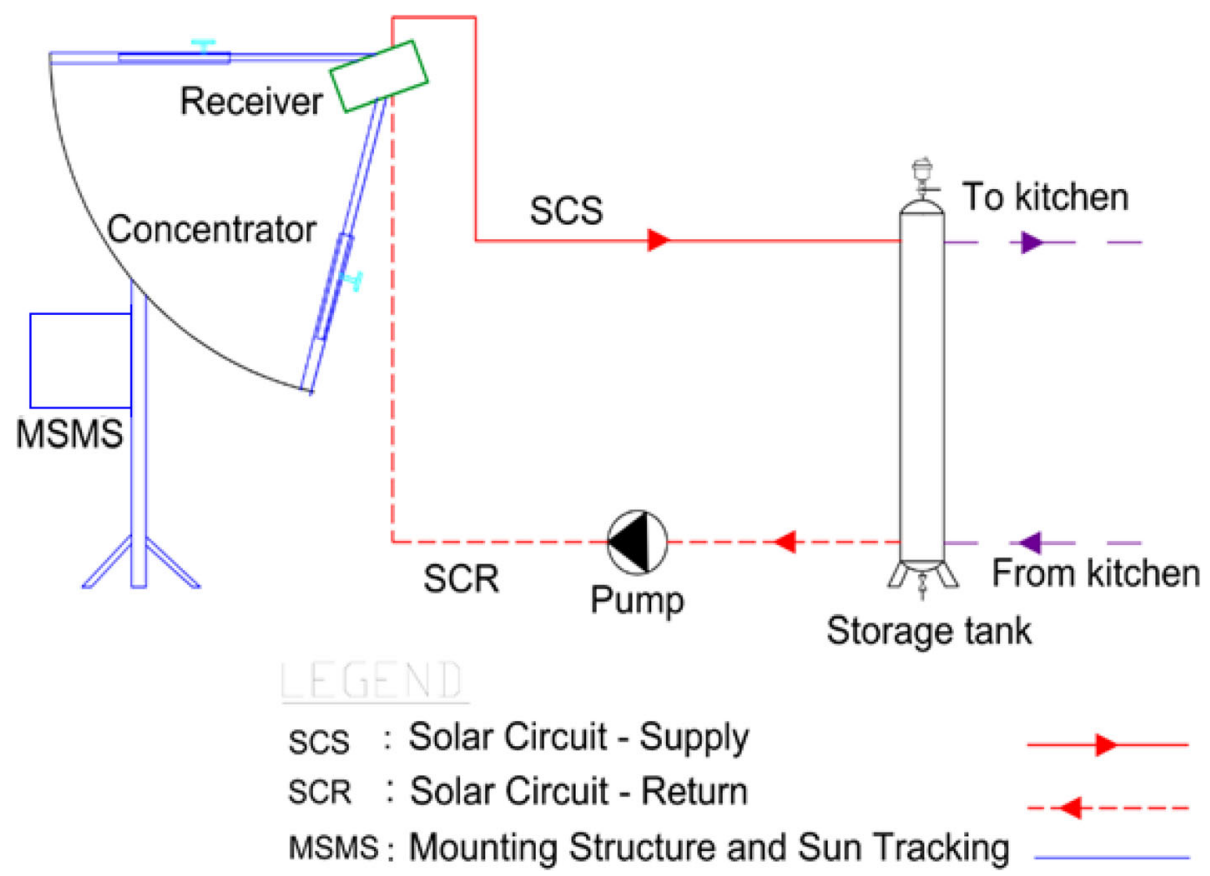

Fig. 1 Schematics of a solar cooking system with a heat storage [3]

$220{ }^{\circ} \mathrm{C}$ ), thermal insulation would be necessary. A storage mainly based on thermal oil is much more efficient than on aluminum crossed by thermal oil channels. Comparison between the current heat storage and the direct cooker for boiling water even with a standard pot shows that heat storage increases cooking time from 27 to $38 \mathrm{~min}$. He also showed that the selective coating does not drastically improve the efficiency of the system, but the use of an evacuated tube around the absorber reduces by a factor of 2 the charging time of the heat storage.

\section{Methods}

System description and heat transfer processes System description and operation

Figure 1 shows the schematics of the experimental system used in this study and described in more details in a previous paper [3]. The system is composed of the following elements: a solar concentrator, a receiver, a heat storage tank, and a circulation pump placed in the primary fluid circuit. Synthetic oil SAE-40 is used as the heat transfer fluid, and the system has a two-axis tracking mechanism. Figure 2 shows pictures of the second experimental setup.

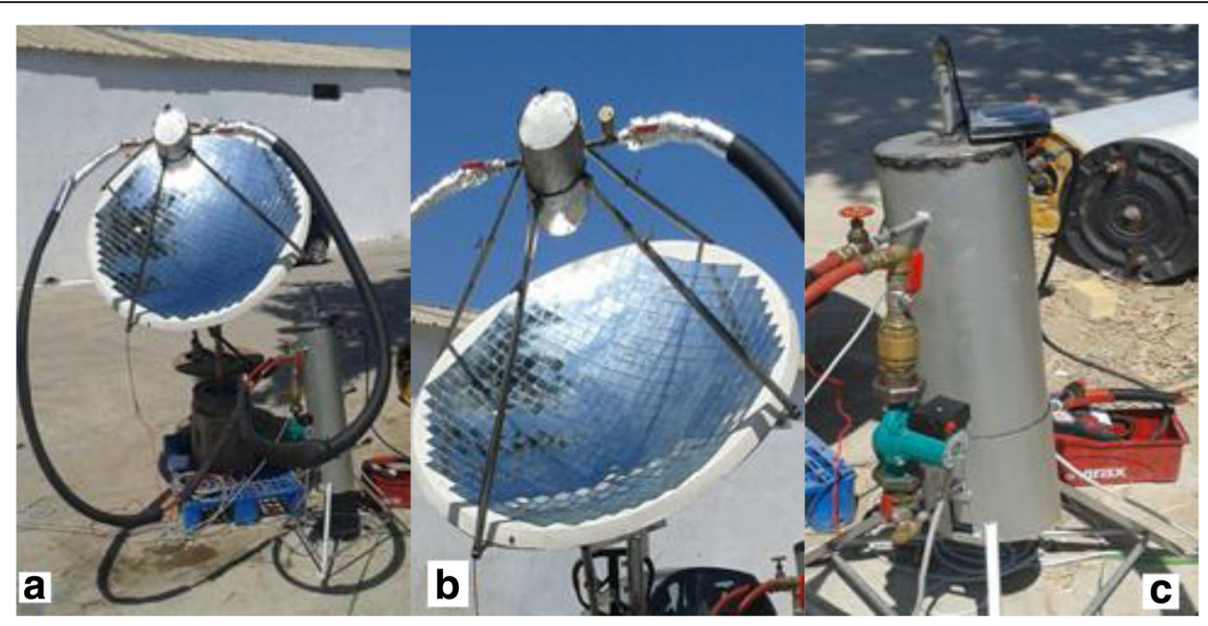

Fig. 2 Detailed pictures of the second experimental setup. a Complete system. b Concentrator and receiver. c Heat storage tank and circulation pump 
The key part of the PSCS is the receiver also called the absorber which is composed of two black iron cylinders as shown in Fig. 3. The inner cylinder, with a volume of $1.57 \mathrm{l}$, has a thickness of $1.5 \mathrm{~mm}$, a diameter of $0.1 \mathrm{~m}$, and a length of $0.2 \mathrm{~m}$ and is black acrylic painted to maximize absorption of solar radiation. The outer cylinder is larger with a thickness of $1 \mathrm{~mm}$, a diameter of $0.2 \mathrm{~m}$, and a length of $0.25 \mathrm{~m}$. The absorber is maintained at the focal point by three square sliding iron tube arms expandable from 0.4 to $0.6 \mathrm{~m}$ in length. Glass wool is placed between the two cylinders, as insulation to reduce heat losses. The front of the receiver can optionally be equipped with a glass cover. Table 1 gives the system size parameters and optical properties of each material in the two devices.

\section{Heat transfer modes}

Incident sunlight reaching the parabolic dish is concentrated on the glass cover at the front face of the receiver. A first part of the concentrated solar radiation is reflected to the ambient, the glass absorbs a second part, and a third part is transmitted through the glass cover. The latter part is absorbed by the receiver plate. A small part is reflected back to the glass cover. Heat is transmitted to the fluid via the black-painted metal absorber. The selective coating layer has a high absorptance and a low emittance in order to reduce thermal radiation losses. Figure 4 shows a cross section of the receiver and all heat transfer processes involved. The absorber is considered to be very rigid, and its properties are not affected by temperature.

The thermal resistances and the different modes of heat transfer between the external environment (ambient and sky), the receiver, and the fluid are depicted in Fig. 5. We take into account the energy stored in each node and consider a one-dimensional space temperature variation in the receiver and heat storage tank. The different heat losses, which are conduction through the receiver insulation, convection from the receiver to the ambient air, and radiation from the receiver to the sky, are also considered in a similar manner as Guendouz [7] and Rongrong et al. [8]. For evaluating the different heat loss coefficients, we used the equations presented by Duffie and Beckman [9] and Incropera et al. [10].

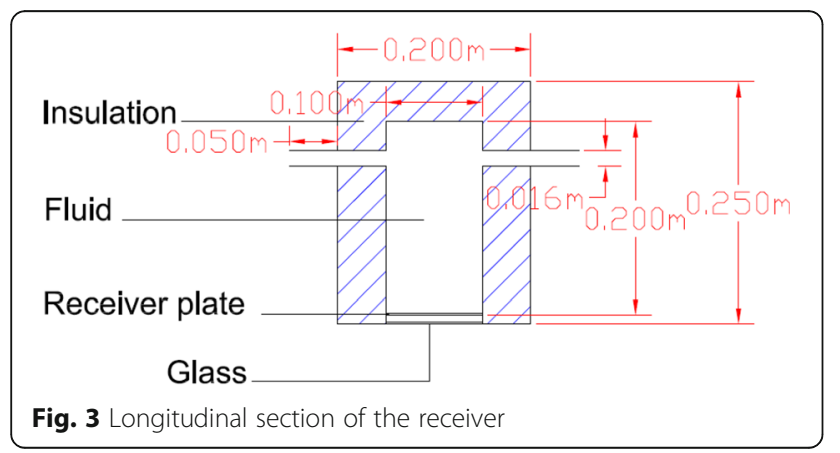

Table 1 System size parameters and optical properties

\begin{tabular}{|c|c|c|c|}
\hline Designation & $\begin{array}{l}\text { First experimental } \\
\text { device }\end{array}$ & $\begin{array}{l}\text { Second experimental } \\
\text { device }\end{array}$ & Unit \\
\hline \multicolumn{4}{|l|}{ Concentrator } \\
\hline Diameter & 0.8 & 1.4 & $\mathrm{~m}$ \\
\hline Depth & 0.08 & 0.16 & $\mathrm{~m}$ \\
\hline Focal length & 0.5 & 0.77 & $\mathrm{~m}$ \\
\hline Total mass & 5.1 & 24.7 & $\mathrm{~kg}$ \\
\hline Surface area & 0.353 & 1.41 & $\mathrm{~m}^{2}$ \\
\hline Mirror reflectance & 0.85 & * & \\
\hline \multicolumn{4}{|l|}{ Receiver } \\
\hline Diameter & 0.1 & * & $\mathrm{m}$ \\
\hline $\begin{array}{l}\text { Length perpendicular } \\
\text { to the aperture }\end{array}$ & 0.20 & * & $\mathrm{m}$ \\
\hline Square sliding tube & $0.4-0.6$ & $0.7-0.9$ & $\mathrm{~m}$ \\
\hline Insulation thickness & 0.05 & $*$ & $\mathrm{~m}$ \\
\hline Thickness & 1.5 & * & $\mathrm{mm}$ \\
\hline Mass & 2.34 & * & $\mathrm{kg}$ \\
\hline Surface area & 0.079 & * & $\mathrm{m}^{2}$ \\
\hline Intercept factor & 0.9 & * & \\
\hline Absorptance & 0.8 & * & \\
\hline \multicolumn{4}{|l|}{ Glass cover } \\
\hline Diameter & 0.12 & $*$ & $\mathrm{~m}$ \\
\hline Thickness & 6 & * & $\mathrm{mm}$ \\
\hline Mass & 0.23 & * & $\mathrm{kg}$ \\
\hline Surface area & 0.014 & * & $\mathrm{m}^{2}$ \\
\hline Absorptance & 0.01 & * & \\
\hline Transmittance & 0.8 & * & \\
\hline \multicolumn{4}{|l|}{ Storage } \\
\hline Diameter & & 0.12 & $\mathrm{~m}$ \\
\hline Length & & 0.65 & $\mathrm{~m}$ \\
\hline Insulation thickness & & 0.06 & $\mathrm{~m}$ \\
\hline Thickness & & 3.0 & $\mathrm{~mm}$ \\
\hline Mass & & 8.97 & $\mathrm{~kg}$ \\
\hline Surface area & & 0.26 & $\mathrm{~m}^{2}$ \\
\hline
\end{tabular}

*Same value in both systems

\section{Results and discussion}

\section{Governing equations and numerical solution}

The present model of the PSCS considers all the abovementioned heat transfer processes, takes into account the presence of the glazing on the receiver, and assumes one-dimensional variations of the temperature along the receiver and the storage tank. The first law of thermodynamics is applied between times $t$ and $t+\Delta t$ to various system components to obtain the governing energy balance equations in a convenient explicit finite difference form ready for numerical solution.

- Solar concentrator: 


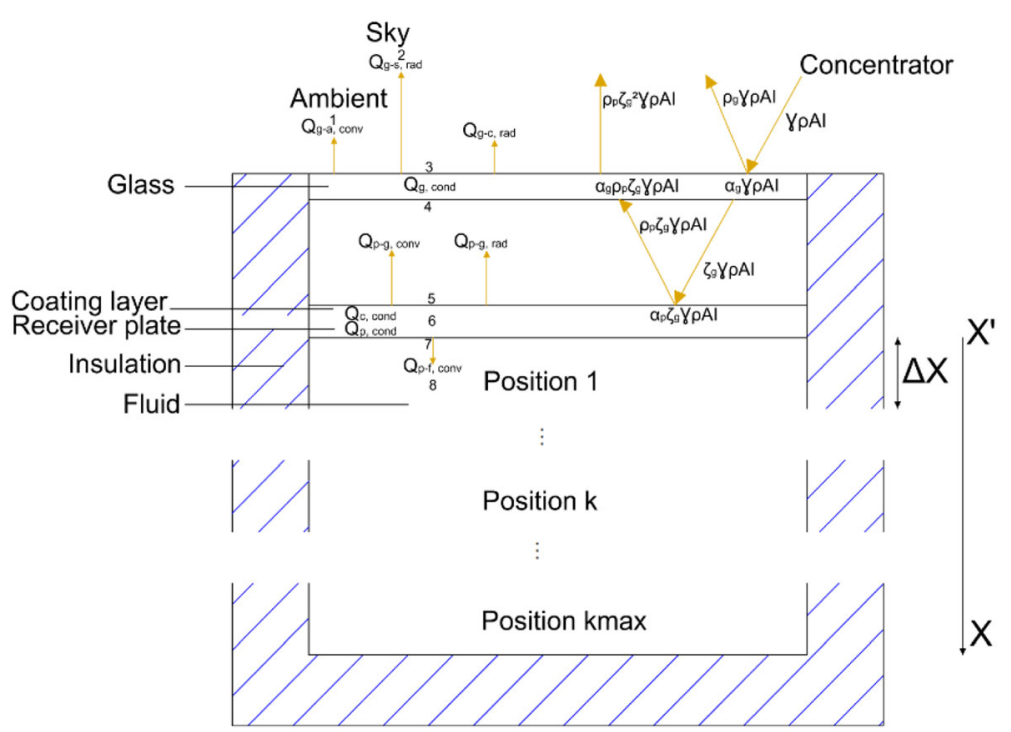

Fig. 4 Cross section of the receiver with heat transfer processes

$m_{c} C_{c} \Delta T_{c}=\left[(1-\rho) I_{c}-h_{1}\left(T_{c}-T_{a}\right)-h_{2}\left(T_{c}-T_{s}\right)-h_{3}\left(T_{c}-T_{g}\right)\right] A_{c} \Delta t$

- Glass cover:

$$
\begin{aligned}
{ }_{m g} C_{g} \Delta T_{g}= & {\left[\alpha_{g} \gamma \rho A_{c} I_{c}+h_{3}\left(T_{c}-T_{g}\right) A_{c}-\left(h_{4}\left(T_{g}-T_{a}\right)\right.\right.} \\
& \left.\left.+h_{5}\left(T_{g}-T_{s}\right)\right) A_{g}+\left(h_{6}+h_{7}\right)\left(T_{p}-T_{g}\right) A_{g}\right] \Delta t
\end{aligned}
$$

$$
\begin{aligned}
m_{p} C_{p} \Delta T_{p}= & {\left[\alpha_{p} \tau_{g} \gamma \rho A_{c} I_{c}-h_{8}\left(T_{p}-T_{f, r}^{1}\right) A_{p}\right.} \\
& \left.-\left(h_{6}+h_{7}\right)\left(T_{p}-T_{g}\right) A_{g}\right] \Delta t
\end{aligned}
$$

- Fluid portion in position 1 of the receiver:

$$
\begin{aligned}
m_{r, k} C_{f} \Delta T_{f, r}^{1}= & {\left[\dot{m} C_{f}\left(T_{f, r}^{2}-T_{f, r}^{1}\right)+h_{8}\left(T_{p}-T_{f, r}^{1}\right) A_{p}\right.} \\
& \left.-\frac{\lambda_{f}}{\Delta X_{r}}\left(T_{f, r}^{1}-T_{f, r}^{2}\right) A_{P}-h_{g}\left(T_{f, r}^{1}-T_{a}\right) S_{u r}\right) \Delta t
\end{aligned}
$$

The intercept factor $\gamma$ accounts for various imperfections in the system operation: shadowing, tracking system inaccuracy, geometry, mirror clearness, dust on the glass cover, and miscellaneous factors [11].

$$
\gamma=\prod_{i=1}^{6} \gamma_{i}
$$

- Fluid portion in intermediate position $\mathrm{k}(1<k<k \max )$ of the receiver:

$$
\begin{aligned}
m_{r, k} C_{f} \Delta T_{f, r}^{k}= & {\left[\dot{m} C_{f}\left(T_{f, r}^{k+1}-T_{f, r}^{k}\right)+\frac{\lambda_{f}}{\Delta X_{r}}\left(T_{f, r}^{k-1}-T_{f, r}^{k}\right) A_{P}\right.} \\
& \left.-\frac{\lambda_{f}}{\Delta X_{r}}\left(T_{f, r}^{k}-T_{f, r}^{k+2}\right) A_{P}-h_{g}\left(T_{f, r}^{k}-T_{a}\right) S_{u r}\right) \Delta t
\end{aligned}
$$

- Receiver plate:
- Fluid portion in position $k$ max of the receiver:

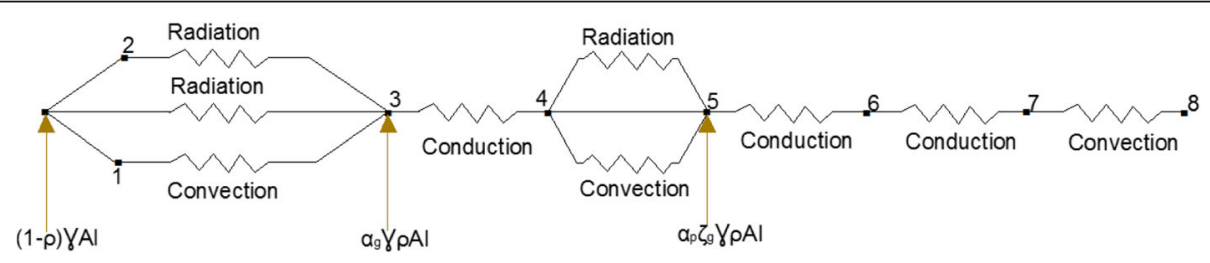

Fig. 5 Equivalent thermal resistance model 


$$
\begin{aligned}
m_{r, k} C_{f} \Delta T_{f, r}^{k \max }= & {\left[\dot{m} C_{f}\left(T_{f, r}^{1}-T_{f, r}^{k \max }\right)+\frac{\lambda_{f}}{\Delta X_{r}}\right.} \\
& \left(T_{f, r}^{k \max -1}-T_{f, r}^{k \max }\right) A_{P}-h_{g} \\
& \left.\left(T_{f, r}^{k \max }-T_{a}\right)\left(S_{u r}+A_{P}\right)\right] \Delta t
\end{aligned}
$$

Similarly, the storage tank is divided into imax fluid zones.

- Fluid portion in position 1 of the storage tank:

$$
\begin{aligned}
m_{r, k} C_{f} \Delta T_{f, r}^{1}= & {\left[\dot{m} C_{f}\left(T_{f, r}^{2}-T_{f, r}^{1}\right)+\frac{\lambda_{f}}{\Delta X_{r}}\left(T_{f, r}^{2}-T_{f, r}^{1}\right) A_{p}-h_{g}^{\prime}\right.} \\
& \left.\left(T_{f, r}^{1}-T_{a}\right)\left(S_{u r}+A_{s}\right)\right) \Delta t
\end{aligned}
$$

\begin{tabular}{|c|c|c|}
\hline Designation & Value & Unit \\
\hline Initial temperature & 20 & ${ }^{\circ} \mathrm{C}$ \\
\hline Receiver length step & 0.07 & $\mathrm{~m}$ \\
\hline Storage length step & 0.22 & $\mathrm{~m}$ \\
\hline Receiver plate surface area & 0.008 & $m^{2}$ \\
\hline Storage cross-section area & 0.01 & $m^{2}$ \\
\hline Receiver lateral surface area & 0.021 & $m^{2}$ \\
\hline Storage lateral surface area & 0.078 & $m^{2}$ \\
\hline Concentrator specific heat & 800 & $\mathrm{~J} \mathrm{~kg}^{-1}{ }^{\circ} \mathrm{C}^{-1}$ \\
\hline Glass specific heat & 800 & $\mathrm{~J} \mathrm{~kg}^{-1}{ }^{\circ} \mathrm{C}^{-1}$ \\
\hline Heat transfer fluid & SAE-40 oil & \\
\hline Fluid specific heat & $1850-2350$ & $\mathrm{~J} \mathrm{~kg}^{-1}{ }^{\circ} \mathrm{C}^{-1}$ \\
\hline Receiver plate specific heat & 470 & $\mathrm{~J} \mathrm{~kg}^{-1}{ }^{\circ} \mathrm{C}^{-1}$ \\
\hline Fluid thermal conductivity & $0.137-0.125$ & $W m^{-1}{ }^{\circ} \mathrm{C}^{-1}$ \\
\hline Insulation thermal conductivity & 0.04 & $W m^{-1}{ }^{\circ} \mathrm{C}^{-1}$ \\
\hline Receiver plate mass & 0.09 & $\mathrm{~kg}$ \\
\hline Mass flow rate & 0.005 & $\mathrm{~kg} \mathrm{~s}^{-1}$ \\
\hline CHTC concentrator to ambient & 9.0 & $W m^{-2}{ }^{\circ} \mathrm{C}^{-1}$ \\
\hline RHTC concentrator to sky & 1.0 & $W m^{-2}{ }^{\circ} \mathrm{C}^{-1}$ \\
\hline RHTC concentrator to glass & 0.1 & $W m^{-2}{ }^{\circ} \mathrm{C}^{-1}$ \\
\hline CHTC glass to ambient & 12.0 & $\mathrm{~W} \mathrm{~m}^{-2}{ }^{\circ} \mathrm{C}^{-1}$ \\
\hline RHTC glass to sky & 0.0 & $\mathrm{~W} \mathrm{~m}^{-2}{ }^{\circ} \mathrm{C}^{-1}$ \\
\hline CHTC plate to glass & 6.0 & $W m^{-2}{ }^{\circ} \mathrm{C}^{-1}$ \\
\hline RHTC plate to glass & 6.0 & $W m^{-2}{ }^{\circ} \mathrm{C}^{-1}$ \\
\hline CHTC plate to fluid & 87.0 & $W m^{-2}{ }^{\circ} \mathrm{C}^{-1}$ \\
\hline GHTC receiver to ambient & 18.0 & $W m^{-2}{ }^{\circ} \mathrm{C}^{-1}$ \\
\hline GHTC storage to ambient & 0.5 & $\mathrm{~W} \mathrm{~m}^{-2}{ }^{\circ} \mathrm{C}^{-1}$ \\
\hline
\end{tabular}

- Fluid portion in position $i \quad(1<i<i \max )$ of the storage tank:

Table 2 Simulation parameters

CHTC Convection Heat Transfer Coefficient, RHTC Radiation Heat Transfer Coefficient, GHTC Global Heat Transfer Coefficient

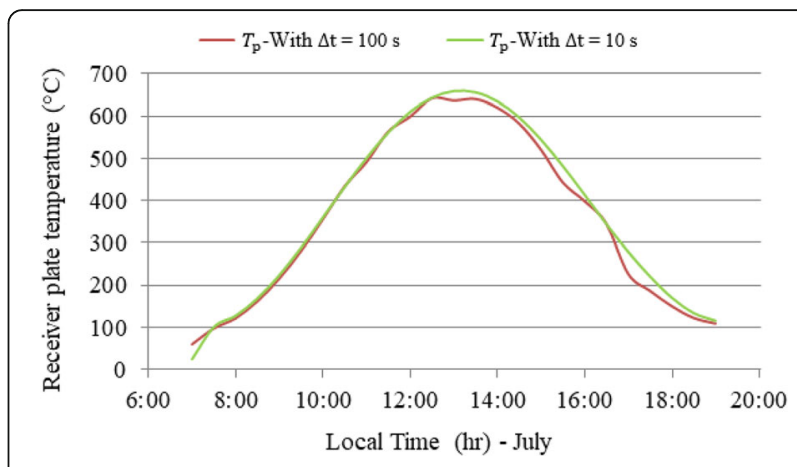

Fig. 6 Time variation of the receiver plate temperature at different time steps

$$
\begin{aligned}
m_{s, i} C_{f} \Delta T_{f, s}^{i}= & {\left[C_{f}\left(T_{f, s}^{i+1}-T_{f, s}^{i}\right)+\frac{\lambda_{f}}{\Delta X_{s}}\left(T_{f, s}^{i+1}-T_{f, s}^{i}\right) A_{s}\right.} \\
& \left.-\frac{\lambda_{f}}{\Delta X_{s}}\left(T_{f, s}^{i}-T_{f, s}^{i-1}\right) A_{S}-h_{g}^{\prime}\left(T_{f, s}^{i}-T_{a}\right) S_{u s}\right) \Delta t
\end{aligned}
$$

- Fluid portion in position $i \max$ of the storage tank:
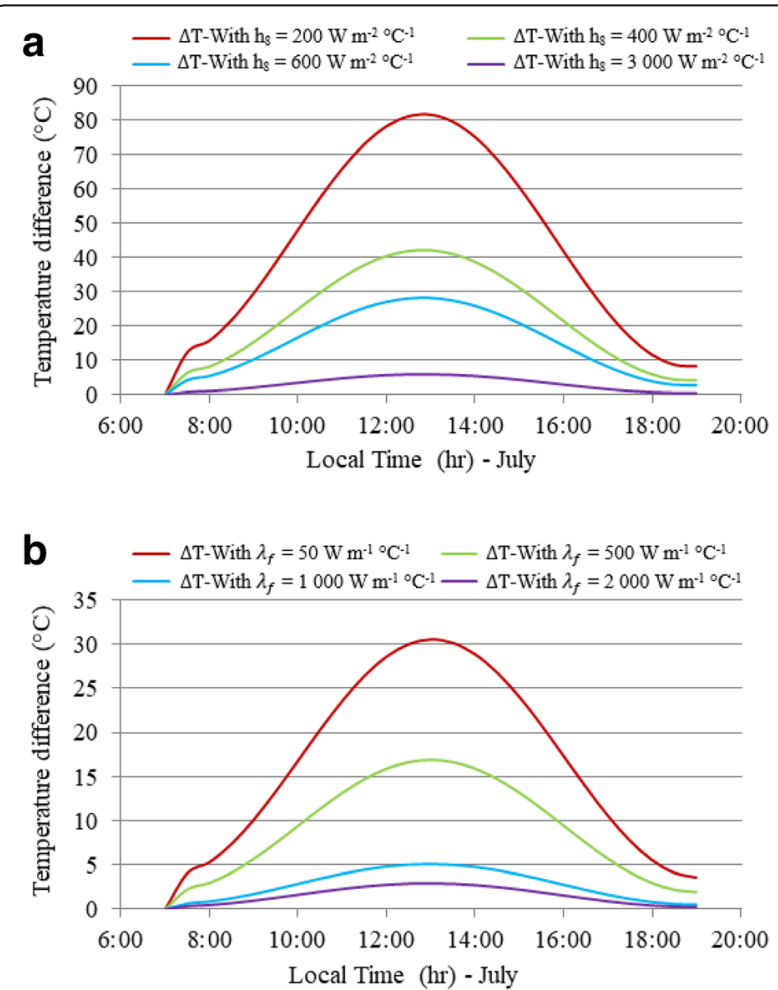

Fig. 7 Time variation of the temperature difference between the plate and the fluid when we increase $\mathbf{a}$ the heat transfer coefficient and $\mathbf{b}$ the fluid thermal conductivity 


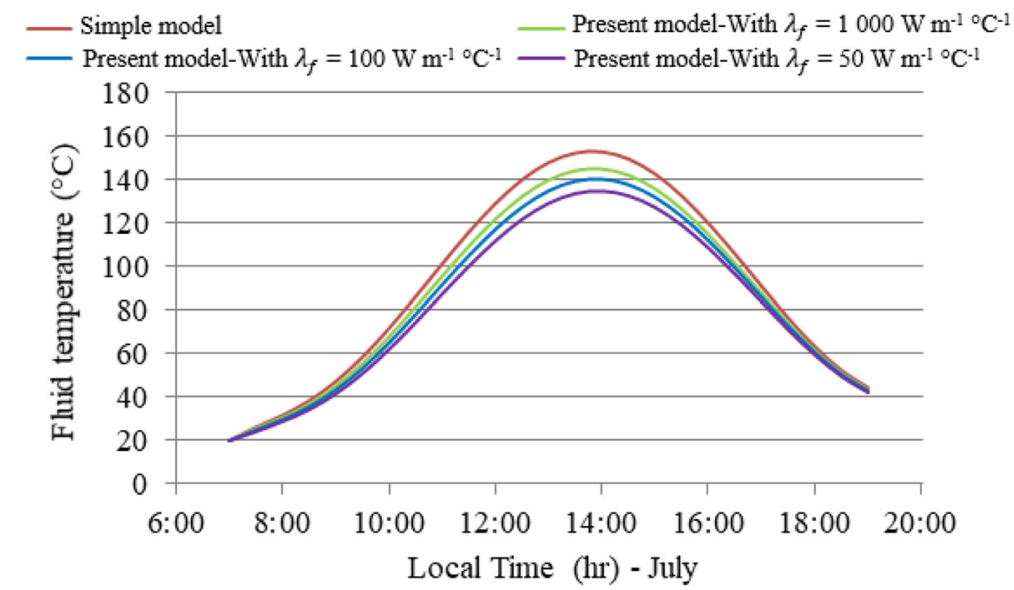

Fig. 8 Comparison of the present model with the simple model of $[12,13]$
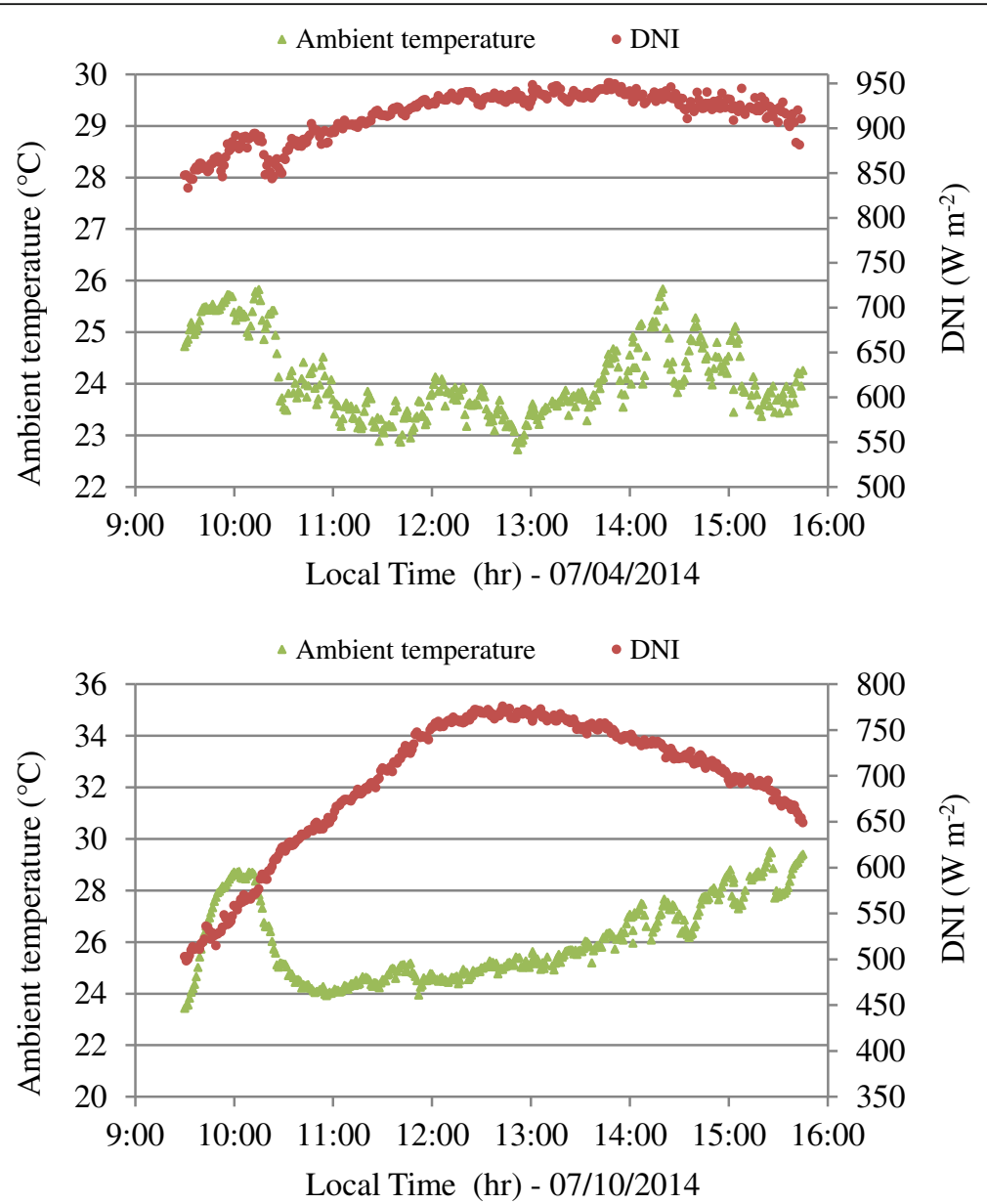

Fig. 9 Time variation of solar radiation and ambient temperature in the closed circuit of the first experimental device 

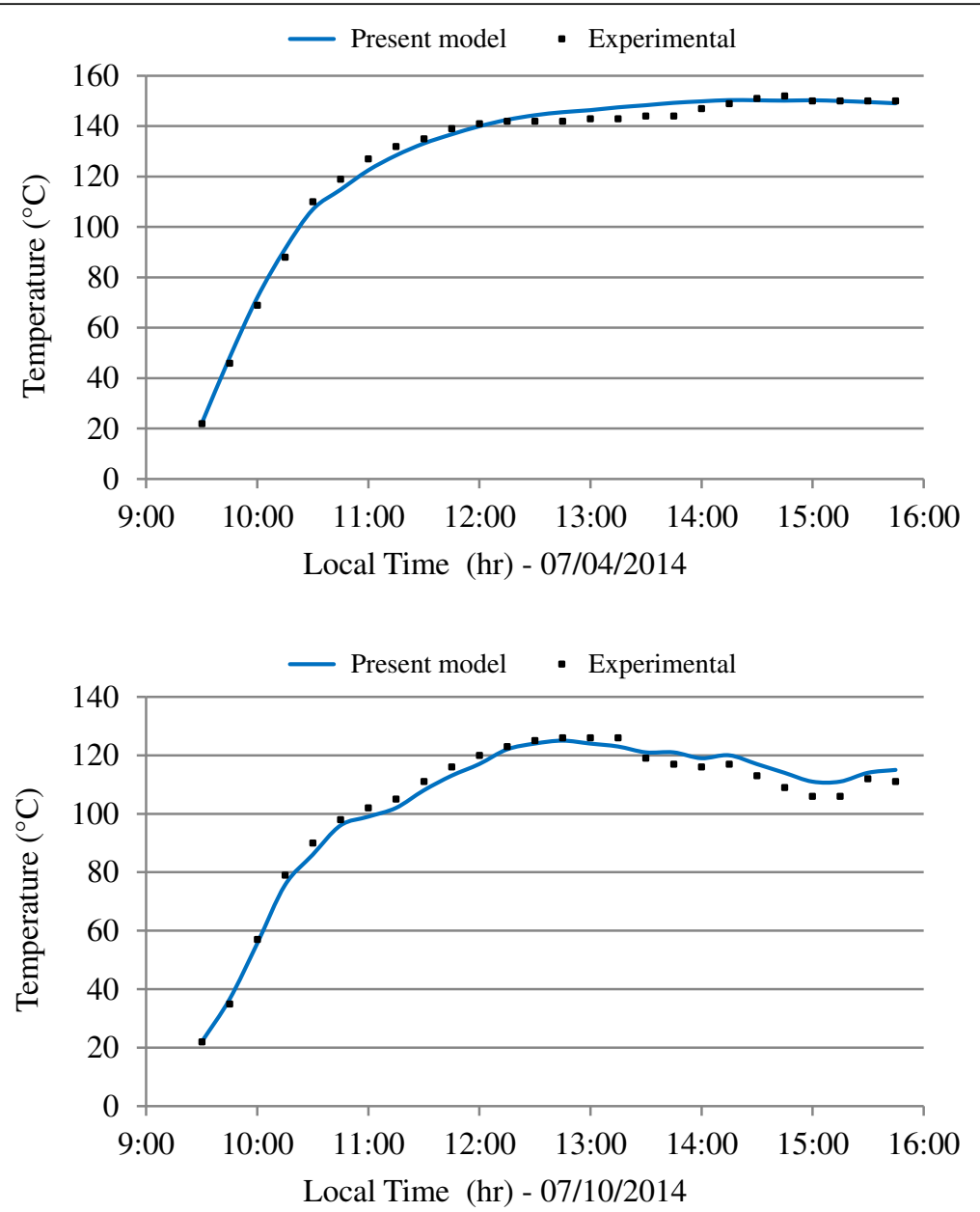

Fig. 10 Measured and predicted fluid temperatures in the receiver in the closed circuit of the first experimental device

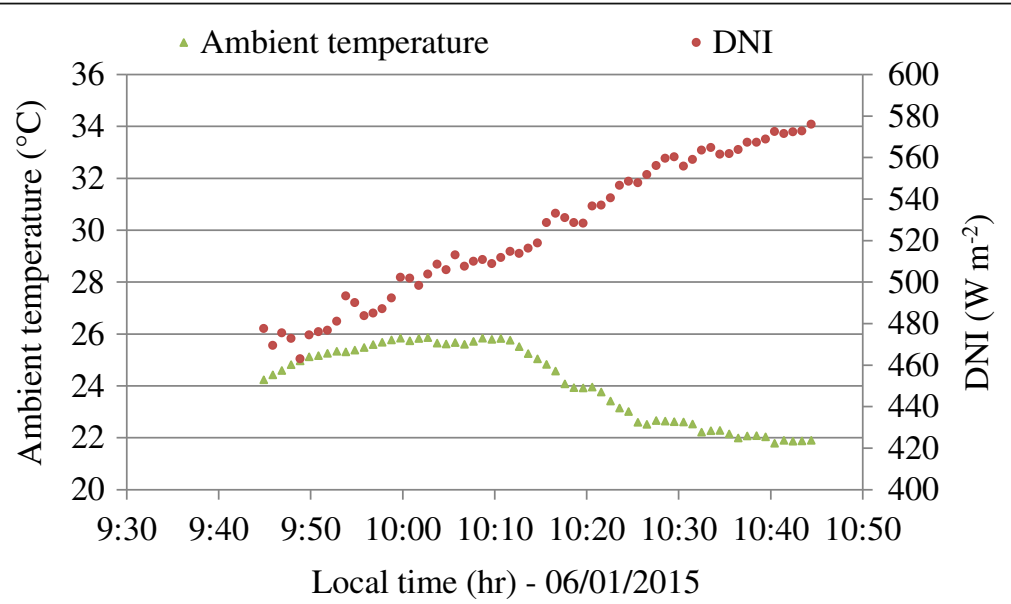

Fig. 11 Time variation of solar radiation and ambient temperature in the closed circuit of the second experimental device 


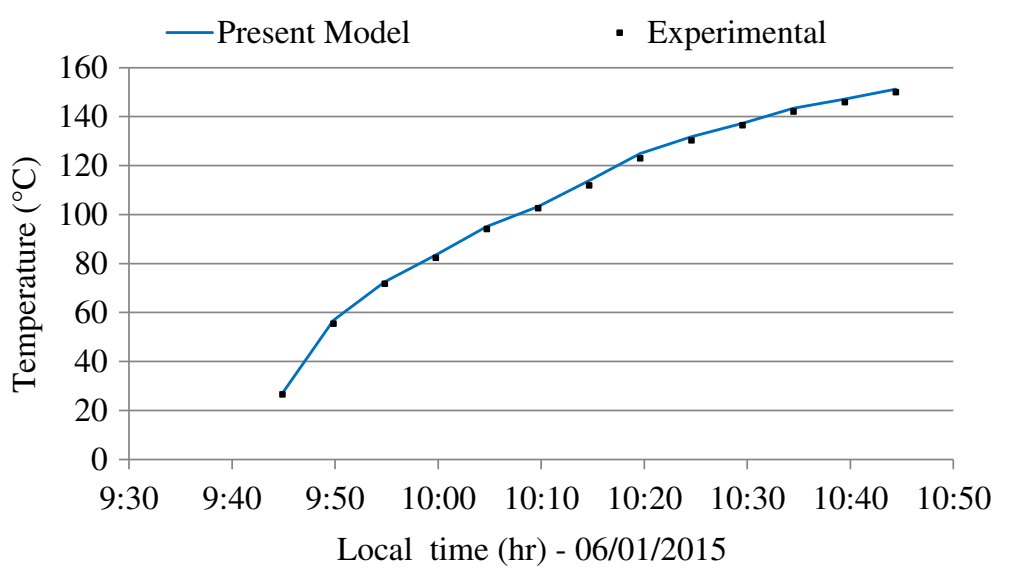

Fig. 12 Measured and predicted fluid temperatures in the receiver in the closed circuit of the second experimental device

$$
\begin{aligned}
m_{s, i} C_{f} \Delta T_{f, s}^{i \max }= & {\left[C_{f}\left(T_{f, r}^{1}-T_{f, s}^{i \max }\right)-\frac{\lambda_{f}}{\Delta X_{s}}\left(T_{f, s}^{i \max }-T_{f, s}^{i \max -1}\right) A_{s}-h_{g}^{\prime}\right.} \\
& \left.\left(T_{f, s}^{i \max }-T_{a}\right)\left(S_{u s}+A_{s}\right)\right) \Delta t
\end{aligned}
$$

The global heat loss coefficients $h_{g}$ and $h_{g}^{\prime}$ are calculated as follows:

$$
h_{g}=h_{g}^{\prime}=\frac{1}{\frac{1}{h_{i}}+\frac{1}{h_{e}}+\frac{e_{\text {ins }}}{\lambda_{\text {ins }}}}
$$

The above governing equations are solved numerically to determine the time variations of the temperatures of the concentrator, the glass cover, the plate on the front face of the receiver, and the fluid at different positions both in the receiver and the storage tank. The simulation parameters for the model are summarized in Table 2.

\section{Convergence and validation of the numerical solution}

The time step is lowered until stability and convergence of the numerical solution is obtained. Figure 6 shows the time variation of the receiver plate temperature at time steps $(\Delta t) 100$ and $10 \mathrm{~s}$; the latter coincides with the curves obtained using smaller value time steps ( 1 and $0.1 \mathrm{~s})$. When the other temperatures are considered, similar behavior is observed, and total stability was obtained with $0.1 \mathrm{~s}$ which is the adopted value throughout the present work.

Our solution was compared with the results of the simpler model described by Newton [12] which consider that the receiver metal plate and the fluid have the same temperature. Zeghib [13] used the same model, but he considers that there are temperature gradients along the receiver. Figure 7 shows that the temperature difference between the receiver plate and the fluid in position 1 tends to vanish when the heat transfer coefficient is infinite (actually larger than $3000 \mathrm{~W} \mathrm{~m}{ }^{-2}{ }^{\circ} \mathrm{C}^{-1}$ ). Similarly, the temperature difference between the plate and the fluid in position $k \max$ decreases to 0 when the fluid thermal conductivity is infinite (actually larger than $2000 \mathrm{~W} \mathrm{~m}^{-1}{ }^{\circ} \mathrm{C}^{-1}$ ).

Figure 8 presents the fluid temperature at position $k$ max in the receiver obtained by solving our model using a high heat transfer coefficient (a heat coefficient of $10,500 \mathrm{~W} \mathrm{~m}{ }^{-2}{ }^{\circ} \mathrm{C}^{-1}$ is taken, to guarantee that the plate temperature and the fluid temperature at position $k=1$ are equal) and varying the fluid thermal conductivity. At higher values $\left(\lambda_{f}\right.$ larger than $6000 \mathrm{~W} \mathrm{~m}^{-1}{ }^{\circ} \mathrm{C}^{-1}$ ), the numerical solution matches the results obtained using the simple model of [12, 13], under the same operating conditions and with the same time step $(0.1 \mathrm{~s})$.

The first experimental system was tested in the region of Rabat (Morocco) during the period from April 24 to July 10, 2014. Tests were conducted from 9:00 am to 5:30 pm local time, under clear sky conditions (see Fig. 9).

Figure 10 compares the measured and the theoretical fluid temperatures in the upper part of the receiver in the closed circuit of the first experimental device using SAE-40 synthetic oil at 15 -min intervals which reached a maximum temperature of $153{ }^{\circ} \mathrm{C}$ after $5 \mathrm{~h}$.

The second experimental system was tested at the same location during the period from May 15 to June

Table 3 Relative and root mean square errors in the closed circuit

\begin{tabular}{llll}
\hline Date & $07 / 04 / 2014$ & $07 / 10 / 2014$ & $06 / 01 / 2015$ \\
\hline RE $(\%)$-receiver & \pm 4.3 & \pm 4.3 & \pm 2.4 \\
RMSE $\left({ }^{\circ} \mathrm{C}\right)$-receiver & 2.8 & 3.0 & 1.2 \\
\hline
\end{tabular}

$R E$ relative error, RMSE root mean square error 

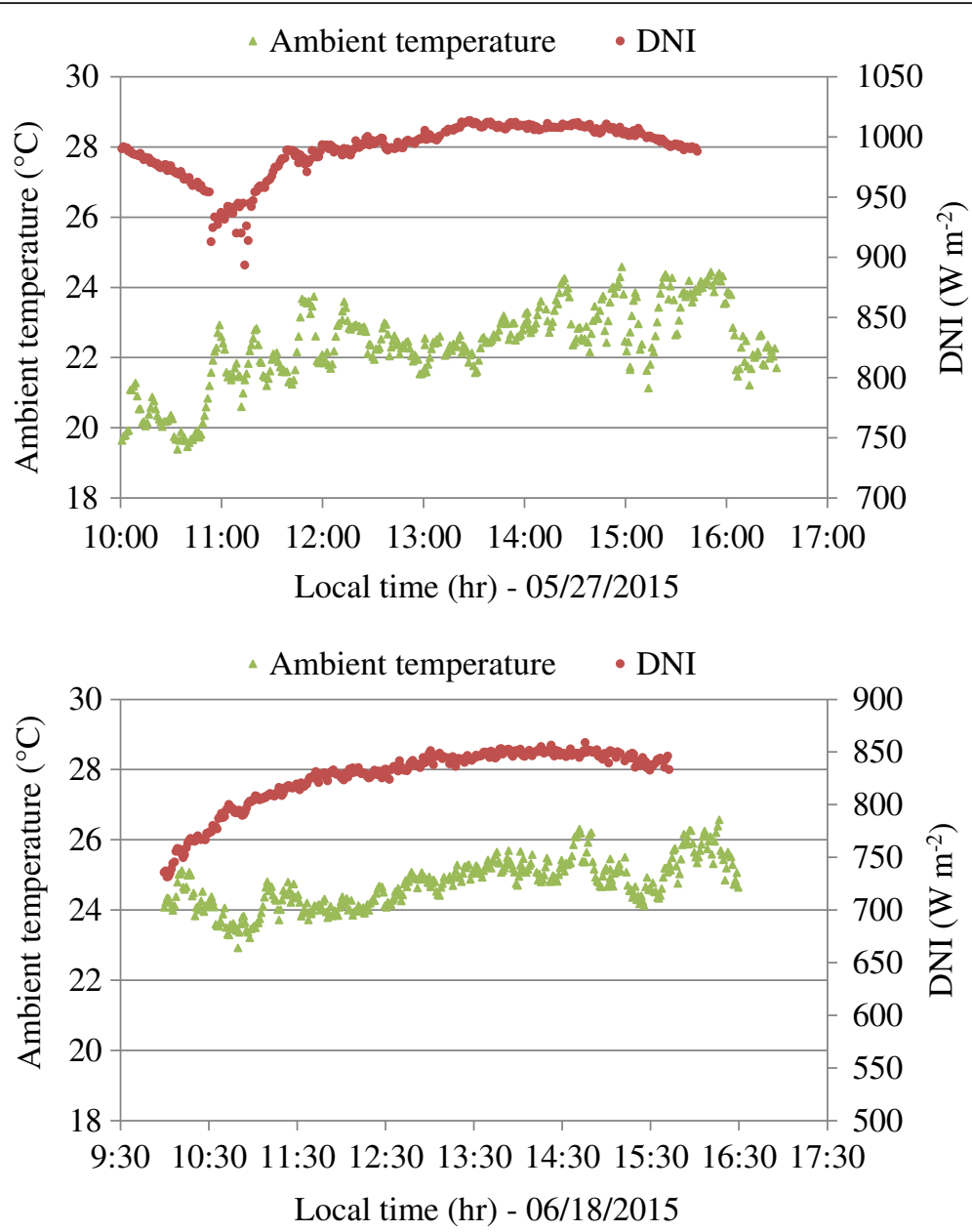

Fig. 13 Time variation of solar radiation and ambient temperature in the open circuit of the second experimental device

18,2015 , under clear sky conditions (see meteorological data in Fig. 11).

The measured and the theoretical fluid temperatures in the upper part of the receiver in the closed circuit of the second experimental device using SAE-40 synthetic oil at 5-min intervals are given in Fig. 12. The maximum fluid temperature was $150^{\circ} \mathrm{C}$ reached after $1 \mathrm{~h}$ of heating.

A good agreement is noticed between the theoretical values and the experimental results. The relative error (RE) is between \pm 2.4 and $\pm 4.3 \%$, and the root mean square error (RMSE), which represents the arithmetic mean of the squares of the differences between the forecasts and the observations, is between 1.2 and $3.0{ }^{\circ} \mathrm{C}$. These values are summarized in Table 3.

The DNI and temperature data used in an open circuit are shown in Fig. 13.

Figure 14 shows the oil temperature measurements in the upper part of the receiver and in the lower part of the storage tank using SAE-40 synthetic oil at 15min intervals. The maximum fluid temperature in the storage was $75{ }^{\circ} \mathrm{C}$.
Table 4 summarizes the relative error and the root mean square error which were, respectively, between \pm 4.0 and $5.9 \%$ and between 1.3 and $1.5{ }^{\circ} \mathrm{C}$ in the receiver and between \pm 4.4 and $\pm 7.5 \%$ and between 1.3 and $1.9{ }^{\circ} \mathrm{C}$ in the storage tank. The increase in RE noted on the day of May 27, 2015, is due to the temperature difference that was greater than $5{ }^{\circ} \mathrm{C}$ between the receiver and the storage tank due to the blocking of the pump shaft at the end of the afternoon.

\section{Parametric analysis}

The performance of a PSCS can be significantly affected by numerous parameters such as weather conditions (solar radiation, wind) that vary according to the site, material optical properties (reflectance, absorptance, emissivity), system design parameters (aspect ratio, rim angle, intercept factor, exposure ratio), and operating parameters (mass flow rate, glazing, air between the glass and the plate on the front face of the receiver, tracking mechanism, fluid nature, heat losses). The following paragraphs present the results of a parametric analysis of the effect of 


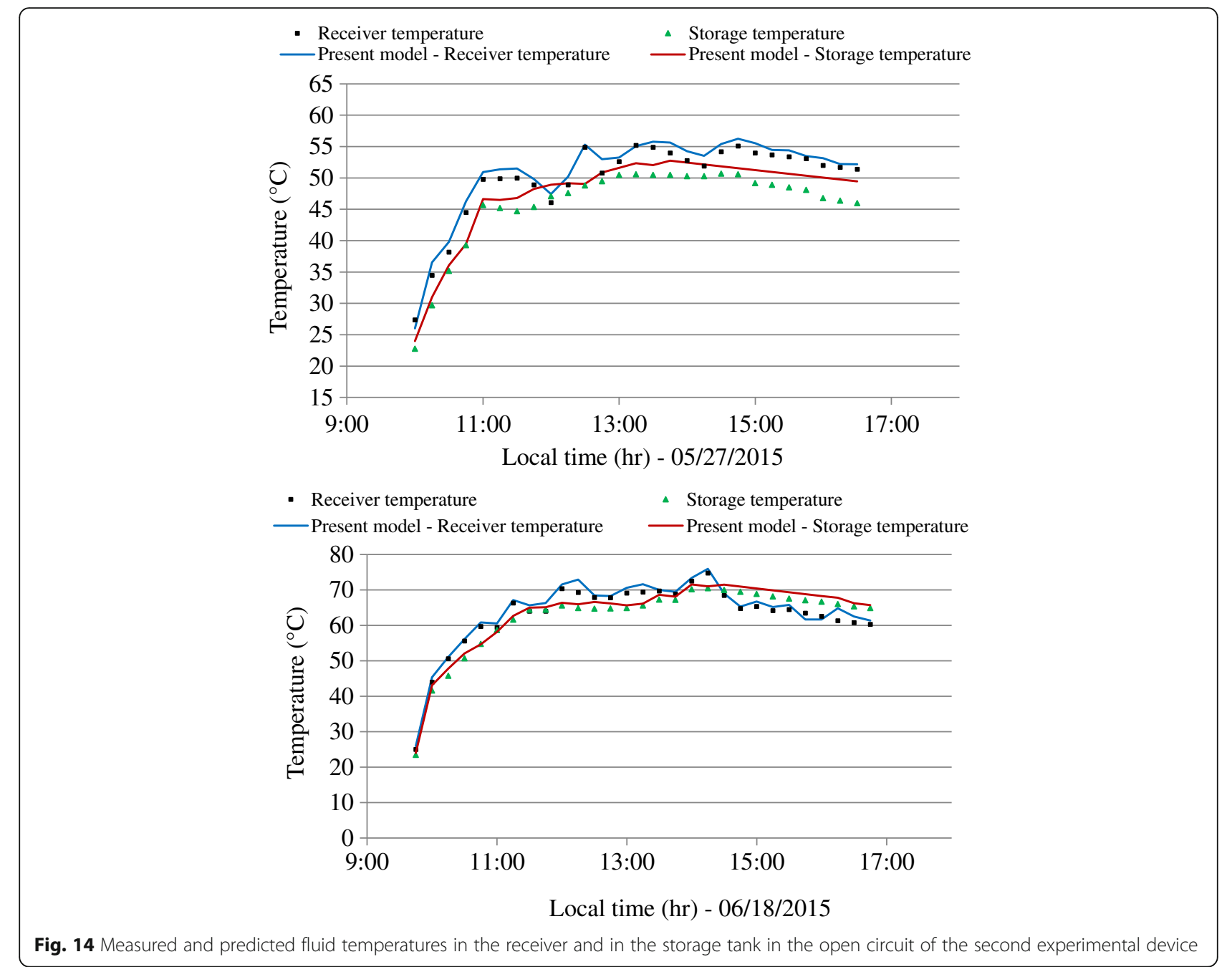

these parameters on the system performance measured by the maximum fluid temperature in the heat storage tank. This choice is dictated by the fact that this one will ensure the cooking (types of food to be cooked and cooking time).

\section{Effect of maximal solar radiation}

Figure 15 shows that the maximum heat storage temperature is greatly affected by maximal solar radiation, which may change depending on the season and

Table 4 Relative and root mean square errors in the open circuit

\begin{tabular}{lll}
\hline Date & $05 / 27 / 2015$ & $06 / 18 / 2015$ \\
\hline RE $(\%)$-receiver & \pm 5.9 & \pm 4.0 \\
RMSE $\left({ }^{\circ} \mathrm{C}\right)$-receiver & 1.3 & 1.5 \\
RE $(\%)$ - storage & \pm 7.5 & \pm 4.4 \\
RMSE $\left({ }^{\circ} \mathrm{C}\right)$ - storage & 1.9 & 1.3 \\
\hline
\end{tabular}

$R E$ relative error, $R M S E$ root mean square error geographic location. The daily maximal radiation varies between 500 and $950 \mathrm{~W} \mathrm{~m}^{-2}$, and a change of daily maximal solar radiation by $50 \mathrm{~W} \mathrm{~m}^{-2}$ increases the maximum storage temperature by about $4{ }^{\circ} \mathrm{C}$. It should be noted that thermal losses also increase due to the increased receiver temperature. However, this increase is smaller than the enhanced absorbed solar energy. Rongrong et al. [8] reported that when solar radiation changes by $20 \mathrm{~W} \mathrm{~m} \mathrm{~m}^{-2}$, the collector output thermal fluid decreases or increases by about $2{ }^{\circ} \mathrm{C}$. Luo et al. [14] found when solar irradiation increases from 900 to $1100 \mathrm{~W} \mathrm{~m}^{-2}$ and decreases from 900 to $700 \mathrm{~W} \mathrm{~m}^{-2}$, the collector outlet temperature will increase or decrease by about $10{ }^{\circ} \mathrm{C}$.

\section{Effects of the material reflectance and absorptance}

Aluminum (0.7), silver mirrors (0.7 to 0.9), and Mylar (0.94) are commonly used as reflectors, whereas copper coated with black paint (0.75) and stainless steel coated with cermet (mixture of ceramics and metal) or black chrome (0.9 to 0.94) are used as absorbers. 


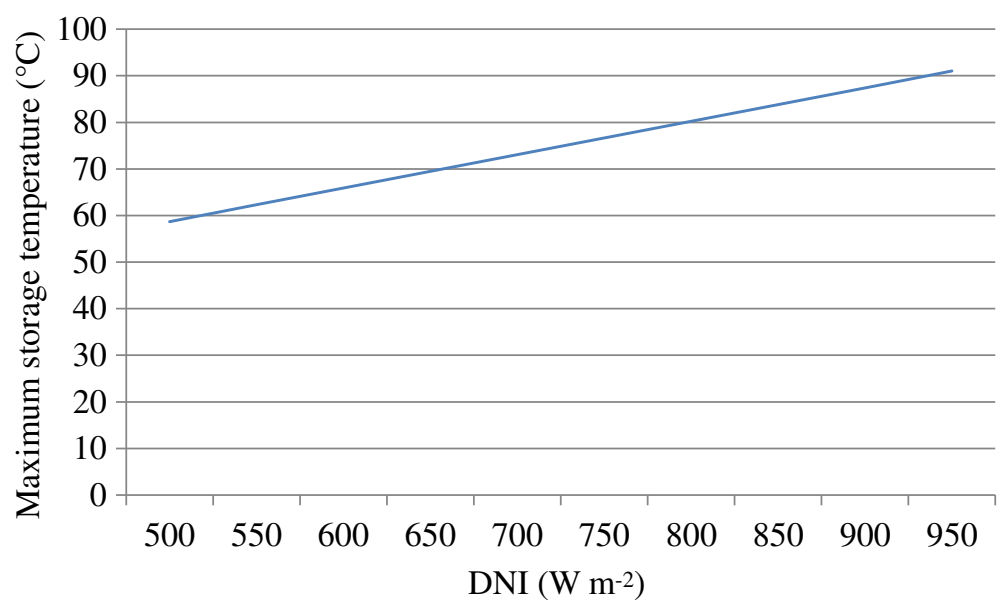

Fig. 15 Maximum storage temperature as a function of solar radiation

Figure 16 illustrates the effect of the reflectance and absorptance of the materials used on the system performance. For a reflectance of 0.75 , an increase of the absorptance from 0.6 to 0.75 will cause an $18{ }^{\circ} \mathrm{C}$ increase of the heat storage temperature. Generally, an increase of $5 \%$ of the reflectance or the absorptance will increase the storage temperature by 3.6 and $3.9^{\circ} \mathrm{C}$, respectively.

\section{Effect of the aspect ratio}

The aspect ratio defined as cavity length to diameter of the receiver is a design parameter which influences system performance. A large diameter increases the "dead area" created by the receiver shadow on the concentrator and the heat losses to ambient air, while a longer cylindrical creates a temperature gradient with slower heat transfer. For a given volume, it is crucial to optimize the aspect ratio as indicated in Fig. 17. The maximum heat storage temperature $\left(85^{\circ} \mathrm{C}\right)$ is reached when the aspect ratio of the receiver is near to 2 . Beyond this value, the temperature decreases because the effect of heat losses particularly radiation in the receiver is greater than the amount of solar radiation intercepted.

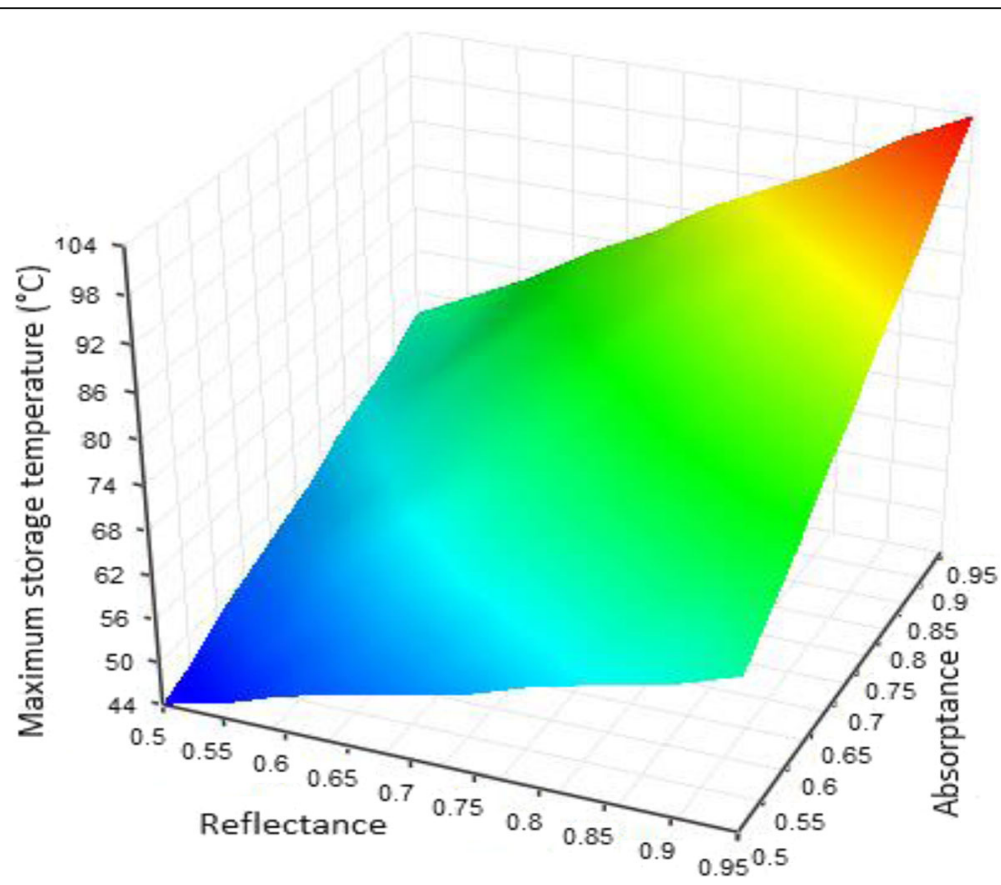

Fig. 16 Maximum storage temperature as a function of the receiver reflectance and absorptance 


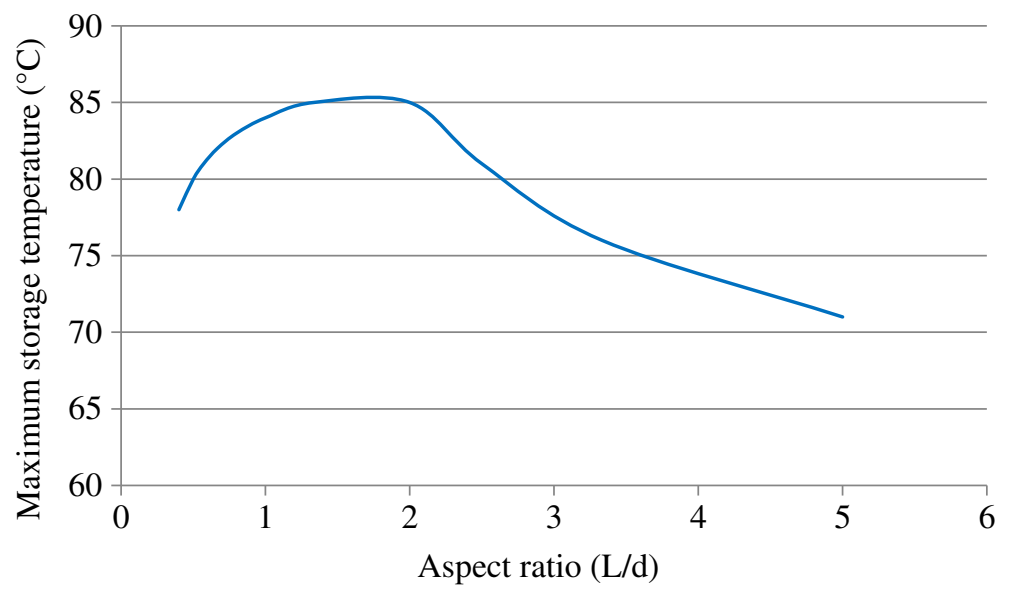

Fig. 17 Maximum storage temperature as a function of the aspect ratio $L / d$

This behavior is close to the results found by other authors [15-17] who also showed increased radiation loss with increasing receiver aperture diameter. Beltran et al. [16] found that the aperture diameter of the cavity reaches a point of maximum efficiency when the aperture diameter is equal to $0.13 \mathrm{~m}$ which corresponds to a receiver aspect of ratio of 1.5. Gil et al. [17] found with a heat loss coefficient of $12 \mathrm{~W} \mathrm{~m}$ ${ }^{-2}{ }^{\circ} \mathrm{C}^{-1}$, the receiver best aspect ratio is 1.9 which is close to our case. Prakash et al. [18] found that the convective loss values increase with opening ratio or exposure ratio while the aspect ratio is equal to 1 . The higher the opening ratio, the greater the convective zone leading to higher convective losses. An increase of about $30-50 \%$ in the convective loss values is observed when the opening ratio increases from 0.5 to 1 .

Paitoonsurikarn et al. [19] used in their work an aspect ratio of 2.2 for the base case and show that the heat flux increases with decreasing cavity aspect ratio for different inclinations. Madadi et al. [20] used many receivers which have an aspect ratio of 2, 2.8, and 3.6 and show that the effect of receiver temperature on radiation loss for greater apertures is higher than smaller apertures. The radiation heat losses from the receiver in comparison with convection heat losses are so low. By decreasing the heat transfer fluid mass flow rate from 0.1 to $0.0083 \mathrm{~kg} \mathrm{~s}$ -1 , with a receiver with an aspect ratio of 2 , the average receiver temperature increases from 197 to $310{ }^{\circ} \mathrm{C}$, the convective heat loss increases only $22 \%$ while the radiation heat loss increases up to $165 \%$.

Abbasi-Shavazia et al. [21] used a receiver which has an aspect ratio of 2, and the comparison of radiation loss values based on bottom surface and areaweighted cavity average temperature shows no more than a $10-20 \%$ difference.

\section{Effect of the thermal fluid mass flow rate}

In high-temperature solar thermal systems with energy storage and automatic control, it is known that fluid mass flow rate is a very important operating parameter. A low mass flow rate causes higher temperatures in the receiver and thus bigger heat losses and lower storage tank temperatures. Conversely, with higher mass flow rate, thermal energy is carried away much faster from the receiver, but also increases the pump size and power consumption. It is therefore important to determine the "optimal" value that yields the highest storage temperature without oversizing the pump. In our case, Fig. 18 shows that increasing the fluid flow rate from 0 to $18 \mathrm{~kg} \mathrm{~h}^{-1}$ increases the storage temperature by $65{ }^{\circ} \mathrm{C}$, and beyond this value, there is no significant improvement of the system performance. These results are very similar to those found by Rongrong et al. [8], Luo et al. [14], and Madadi et al. [20]. The outlet oil temperature in the receiver will be reduced when increasing flow rate in the same working condition.

They found a curve which decreases when the flow rate increases. In this case, the curve of the receiver thermal efficiency presents a maximum at an optimal mass flow rate. The difference between fluid inlet and outlet temperatures is controlled and maintained at $5{ }^{\circ} \mathrm{C}$ in our case, which is commonly used in solar thermal systems.

\section{Effect of insulation thickness}

Heat losses must be carefully analyzed as their assessment can significantly affect the overall system performance accuracy. Thermal insulation of the receiver deserves a careful analysis as a thicker receiver wall reduces thermal losses but it increases the shadow area on the solar concentrator, as well as the receiver weight and system cost. 


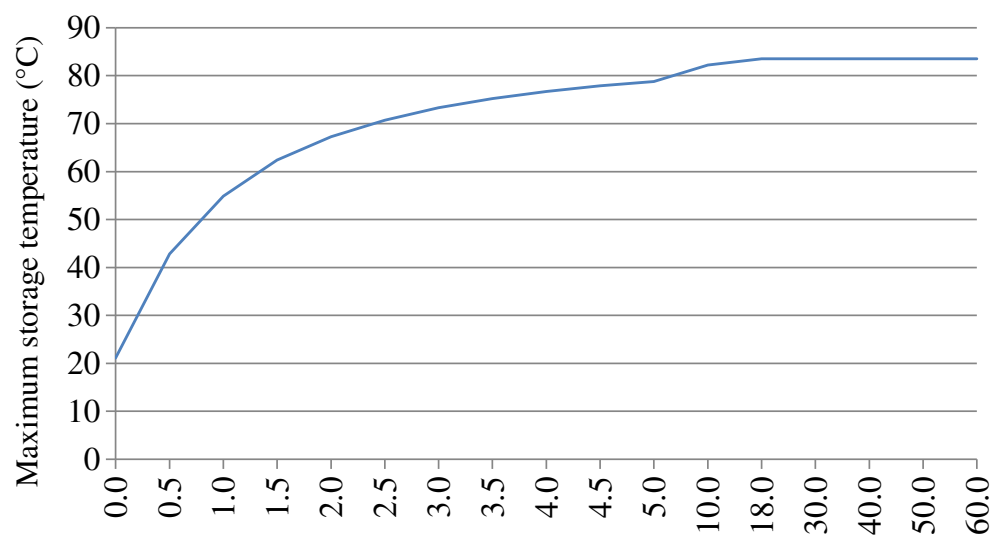

Mass flow rate $\left(\mathrm{kg} \mathrm{h}^{-1}\right)$

Fig. 18 Maximum storage temperature as a function of the thermal fluid mass flow rate

The receiver wall thermal resistance is the inverse of the global heat transfer coefficient resulting from conduction through the receiver and convection heat transfer on the interior and the exterior of the receiver.

An insulation thickness in the receiver between 10 and $80 \mathrm{~mm}$, which corresponds to a global heat loss coefficient between 0.5 and $4.0 \mathrm{~W} \mathrm{~m}^{-2}{ }^{\circ} \mathrm{C}^{-1}$ (or a receiver wall thermal resistance between 0.25 and $\left.2 \mathrm{~m}^{2}{ }^{\circ} \mathrm{CW} \mathrm{W}^{-1}\right)$, is studied. Increasing the insulation thickness from 0.01 to $.08 \mathrm{~m}$ improves the maximum storage temperature by $17{ }^{\circ} \mathrm{C}$ (see Fig. 19). To minimize conduction in the receiver, an insulation thickness of $75 \mathrm{~mm}$ has been suggested as an effective width by Fraser [15].

\section{Conclusions}

The present model of parabolic solar cooking systems introduced with heat storage for continuous use allowed a valuable analysis of the performance of such systems. Improvement over previous simpler models included a non-uniform receiver temperature and temperature difference between the glass, receiver cover, and thermal fluid. The model-governing equations were solved using an explicit finite difference method, and the method was mathematically validated. The results of the simulation were compared with experimental results, which proved that the model predicts adequately the thermal behavior of the described system with a relative error $\pm 4.4 \%$ and a root mean square error of $3{ }^{\circ} \mathrm{C}$. The model was used to carry out a detailed parametric study of the main design and operating parameters which affect the system energy performance. The results show that a change of daily maximum solar radiation of $50 \mathrm{~W} \mathrm{~m}^{-2}$ increases the heat storage temperature by about $4{ }^{\circ} \mathrm{C}$ and an increase of $5 \%$ of the reflectance or the absorptance improves the heat storage temperature by 3.6

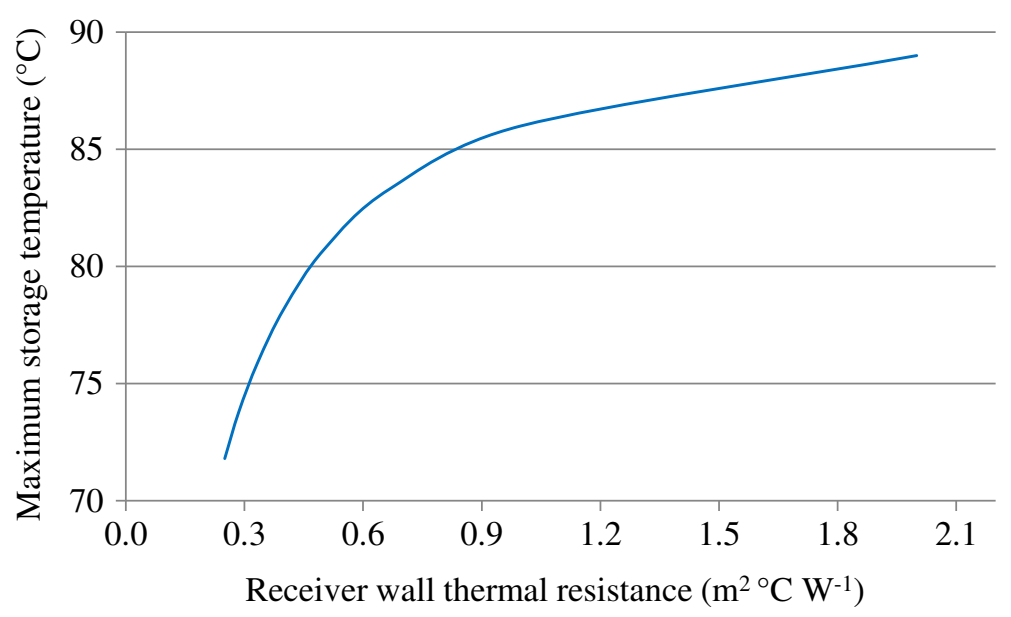

Fig. 19 Maximum storage temperature as a function of receiver wall thermal resistance 
and $3.9{ }^{\circ} \mathrm{C}$, respectively. It was also shown that the best aspect ratio of the receiver is 2 . Increasing the fluid mass flow rate from 0 to $18 \mathrm{~kg} \mathrm{~h}^{-1}$ leads to a maximum storage temperature improvement of $65{ }^{\circ} \mathrm{C}$. Going from an insulation thickness of 0.01 to $0.08 \mathrm{~m}$ increases the maximum storage temperature by $17^{\circ} \mathrm{C}$.

\section{Nomenclature}

\begin{tabular}{|c|c|c|}
\hline$\overline{A_{c}}$ & Concentrator surface area & $m^{2}$ \\
\hline$A_{p}$ & Receiver plate surface area & $m^{2}$ \\
\hline$A_{g}$ & Glass surface area & $m^{2}$ \\
\hline$A_{s}$ & Storage cross-section area & $m^{2}$ \\
\hline$C_{r}$ & Concentrator specific heat & $\mathrm{kJ} \mathrm{kg}^{-1}{ }^{\circ} \mathrm{C}^{-1}$ \\
\hline$C_{g}$ & Glass specific heat & $\mathrm{kJ} \mathrm{kg}{ }^{-1}{ }^{\circ} \mathrm{C}^{-1}$ \\
\hline$C_{f}$ & Fluid specific heat & $\mathrm{kJ} \mathrm{kg}{ }^{-1}{ }^{\circ} \mathrm{C}^{-1}$ \\
\hline$C_{p}$ & Receiver plate specific heat & $\mathrm{kJ} \mathrm{kg}^{-1}{ }^{\circ} \mathrm{C}^{-1}$ \\
\hline$d$ & Receiver diameter & m \\
\hline$e_{\text {ins }}$ & Insulation thickness & $\mathrm{m}$ \\
\hline$h_{1}$ & CHTC concentrator to ambient & $\mathrm{W} \mathrm{m} \mathrm{m}^{-2}{ }^{\circ} \mathrm{C}^{-1}$ \\
\hline$h_{2}$ & RHTC concentrator to sky & $\mathrm{W} \mathrm{m} \mathrm{m}^{-2}{ }^{\circ} \mathrm{C}^{-1}$ \\
\hline$h_{3}$ & RHTC concentrator to glass & $W m^{-2}{ }^{\circ} \mathrm{C}^{-1}$ \\
\hline$h_{4}$ & CHTC glass to ambient & $W m^{-2}{ }^{\circ} \mathrm{C}^{-1}$ \\
\hline$h_{5}$ & RHTC glass to sky & $\mathrm{W} \mathrm{m}^{-2}{ }^{\circ} \mathrm{C}^{-1}$ \\
\hline$h_{6}$ & CHTC plate to glass & $\mathrm{W} \mathrm{m} \mathrm{m}^{-2} \mathrm{C}^{-1}$ \\
\hline$h_{7}$ & RHTC plate to glass & $\mathrm{W} \mathrm{m} \mathrm{m}^{-2}{ }^{\circ} \mathrm{C}^{-1}$ \\
\hline$h_{8}$ & CHTC plate to fluid & $\mathrm{W} \mathrm{m} \mathrm{m}^{-2}{ }^{\circ} \mathrm{C}^{-1}$ \\
\hline$h_{g}$ & GHTC receiver to ambient & $W m^{-2}{ }^{\circ} \mathrm{C}^{-1}$ \\
\hline$h_{g}^{\prime}$ & GHTC storage to ambient & $W m^{-2}{ }^{\circ} \mathrm{C}^{-1}$ \\
\hline$I_{c}$ & Direct normal irradiance & $W m^{-2}$ \\
\hline L & Receiver length perpendicular to the aperture & $\mathrm{m}$ \\
\hline$m$ & Thermal fluid mass flow rate & $\mathrm{kg} \mathrm{s}^{-1}$ \\
\hline$m_{c}$ & Concentrator mass & $\mathrm{kg}$ \\
\hline$m_{g}$ & Glass mass & $\mathrm{kg}$ \\
\hline$m_{p}$ & Receiver plate mass & $\mathrm{kg}$ \\
\hline$m_{r, k}$ & Receiver partial mass in position $k$ & $\mathrm{~kg}$ \\
\hline$m_{s, i}$ & Storage partial mass in position $i$ & $\mathrm{~kg}$ \\
\hline$S_{u r}$ & Receiver partial lateral surface area & $m^{2}$ \\
\hline$S_{\text {us }}$ & Storage partial lateral surface area & $m^{2}$ \\
\hline$T_{a}$ & Ambient temperature & ${ }^{\circ} \mathrm{C}$ \\
\hline$T_{c}$ & Concentrator temperature & ${ }^{\circ} \mathrm{C}$ \\
\hline$T_{f}$ & Fluid temperature & ${ }^{\circ} \mathrm{C}$ \\
\hline$T_{g}$ & Glass temperature & ${ }^{\circ} \mathrm{C}$ \\
\hline$T_{p}$ & Receiver plate temperature & ${ }^{\circ} \mathrm{C}$ \\
\hline$T_{s}$ & Sky temperature & ${ }^{\circ} \mathrm{C}$ \\
\hline
\end{tabular}

\section{Greek symbols}

\begin{tabular}{|c|c|c|}
\hline$g$ & Glass absorptance & \\
\hline$p$ & Receiver plate absorptance & \\
\hline$\gamma$ & Intercept factor & \\
\hline$\Delta t$ & Time step & s \\
\hline$\Delta X_{r}$ & Receiver length step & $\mathrm{m}$ \\
\hline$\Delta X_{5}$ & Storage length step & $\mathrm{m}$ \\
\hline$\lambda_{f}$ & Fluid thermal conductivity & $\mathrm{W} \mathrm{m}^{-1}{ }^{\circ} \mathrm{C}^{-1}$ \\
\hline$\lambda_{\text {ins }}$ & Insulation thermal conductivity & $W m^{-1}{ }^{\circ} \mathrm{C}^{-1}$ \\
\hline$\rho$ & Mirror reflectance & \\
\hline$\tau_{g}$ & Glass transmittance & \\
\hline \multicolumn{3}{|c|}{ Subindex } \\
\hline$c$ & & Concentrator \\
\hline$f$ & & Fluid \\
\hline ins & & Insulation \\
\hline$p$ & & Time step \\
\hline$r$ & & Receiver \\
\hline s & & Storage \\
\hline$g$ & & Glass \\
\hline
\end{tabular}

\section{Authors' contributions}

NM worked as a PhD student under the supervision of AH, wrote the paper, and did the field tests. AH supervised the research work, gave guidance on modeling, and corrected the English text. All authors read and approved the final manuscript.

\section{Competing interests}

This work has received no external funding. I declare that there are no competing interests.

\section{Publisher's Note}

Springer Nature remains neutral with regard to jurisdictional claims in published maps and institutional affiliations.

Received: 10 February 2017 Accepted: 15 September 2017 Published online: 16 October 2017

\section{References}

1. ASDER (2012) Solar cookers - technical presentation. Savoyard Association for the Development of Renewable Energies, Chambery. http://www.asder. asso.fr/phocadownload/cuiseur\%20solaire.pdf.

2. Prasanna UR (2010) Modeling, optimization and design of a solar thermal energy transport system for hybrid cooking application. Ph.D. thesis, Indian Institute of Science. https://www.researchgate.net/publication/204520599_ MODELING_OPTIMIZATION_AND_DESIGN_OF_A_SOLAR_THERMAL_ ENERGY_TRANSPORT_SYSTEM_FOR_HYBRID_COOKING_APPLICATION.

3. Mbodji $\bar{N}$, Hajji A (2016) Performance testing of a parabolic solar concentrator for solar cooking. ASME J Sol Energy Eng 138(4). doi:10.1115/1.4033501 
4. Mawire A, McPherson M, Van den Heetkamp RRJ (2008) Simulated energy and exergy analyses of the charging of an oil-pebble bed thermal energy storage system for a solar cooker. Sol Energy Mater Sol Cells 92:1668-1676. doi:10.1016/j.solmat.2008.07.019

5. Mawire A, McPherson M, Van den Heetkamp RRJ (2010) Discharging simulations of a thermal energy storage (TES) system for an indirect solar cooker. Sol Energy Mater Sol Cells 94(6):1100-1106. doi:10.1016/j. solmat.2010.02.032

6. Mussard M (2013) A solar concentrator with heat storage and selfcirculating liquid. Ph.D. thesis, Norwegian University of Science and Technology, Trondheim, Norway. https://brage.bibsys.no/xmlui/handle/ $11250 / 235100$

7. Guendouz B (2012) Use of solar energy for air conditioning needs. Chapter 3: state of the art of solar collectors and modeling. Magister's thesis, Abou Bakr Belkaid University, Tlemcen, Algeria. http://dspace.univ-tlemcen.dz/ bitstream/112/1200/1/GUENDOUZ-BOUHELAL.pdf

8. Rongrong Z, Yongping Y, Qin Y, Yong Z (2013) Modeling and characteristic analysis of a solar parabolic trough system: thermal oil as the heat transfer fluid. Journal of Renewable Energy. doi:10.1155/2013/389514

9. Duffie JA, Beckman WA (1980) Solar engineering of thermal processes, 2nd edn. John Wiley \& Sons, Inc, New York

10. Incropera F, Dewitt DP, Bergman TL, Lavine AS (2007) Fundamentals of heat and mass transfer, 6th edn. Wiley, New York. http://academic.aua.am/ Sacozey/Public/

Fundamentals\%20of\%20Heat\%20and\%20Mass\%20Transfer\%20\%206th\%20Edition\%20Incropera\%20.pdf.

11. Padilla RV (2011) Simplified methodology for designing parabolic trough solar power plants. Ph.D. thesis, South Florida University. http:// scholarcommons.usf.edu/cgi/viewcontent.cgi?article $=4585 \&$ context=etd.

12. Newton CC (2006) A concentrated solar thermal energy system. Master's thesis, Florida State University, Tallahassee, FL. http://diginole.lib.fsu.edu/ islandora/object/fsu:180899/datastream/PDF/view.

13. Zeghib I (2005) Design and construction of a parabolic solar concentrator. Master's thesis. Mentouri - Constantine University, Algeria. http://archives. umc.edu.dz/bitstream/handle/123456789/10146/ZEG4339.pdf?sequence=1 .

14. Luo N, Yu G, Hou HJ, Yang YP (2015) Dynamic modeling and simulation of parabolic trough solar system. Energy Procedia 69:1344-1348. doi:10.1016/j. egypro.2015.03.137

15. Fraser PR (2008) Stirling dish system performance prediction model. Master of Science, Wisconsin. http://sel.me.wisc.edu/publications/theses/fraser08.zip.

16. Beltran R, Velazquez N, Espericueta AC, Sauceda D, Perez G (2012)

Mathematical model for the study and design of a solar dish collector with cavity receiver for its application in Stirling engines. J Mech Sci Technol 26(10):3311-3321. doi:10.1007/s12206-012-0801-0

17. Gil R, Monné C, Bernal N, Muñoz M, Moreno F (2015) Thermal model of a dish Stirling cavity-receiver. Energies 8:1042-1057. doi:10.3390/en8021042

18. Prakash M, Kedare SB, Nayak JK (2009) Investigations on heat losses from a solar cavity receiver. Sol Energy 83(2):157-170. doi:10.1016/.jsolener.2008.07.011

19. Paitoonsurikarn S, Lovegrove K, Hughes G, Pye J (2011) Numerical investigation of natural convection loss from cavity receivers in solar dish applications. ASME J Sol Energy Eng 133(2):1-10. doi:10.1115/1.4003582

20. Madadi V, Tavakoli T, Rahimi A (2015) Estimation of heat loss from a cylindrical cavity receiver based on simultaneous energy and exergy analyses. J NonEquilib Thermodyn 40(1):49-61. doi:10.1016/j.solener.2008.07.011

21. Abbasi-Shavazia E, Hughes GO, Pye JD (2015) Investigation of heat loss from a solar cavity receiver. Energy Procedia 69:269-278. doi:10.1016/j. egypro.2015.03.031

\section{Submit your manuscript to a SpringerOpen ${ }^{\circ}$ journal and benefit from:}

- Convenient online submission

- Rigorous peer review

- Open access: articles freely available online

- High visibility within the field

- Retaining the copyright to your article

Submit your next manuscript at $\gg$ springeropen.com 